\section{(2) \\ BRAZIULIAN JOURNAL \\ OF MEDICAL AND BIOLOGICAL RESEARCH}

www.bjournal.com.br
ISSN 0100-879X

Volume 45 (3) 179-290 March 2012

BIOMIEDICAL SCIENCES

AND

CLINICAL INVESTIGATION

Braz J Med Biol Res, March 2012, Volume 45(3) 250-255

doi: 10.1590/S0100-879X2012007500027

Cardiovascular effects of the intracerebroventricular injection of adrenomedullin: roles of the peripheral vasopressin and central cholinergic systems

B. Cam-Etoz, N. Isbil-Buyukcoskun and K. Ozluk

The Brazilian Journal of Medical and Biological Research is partially financed by

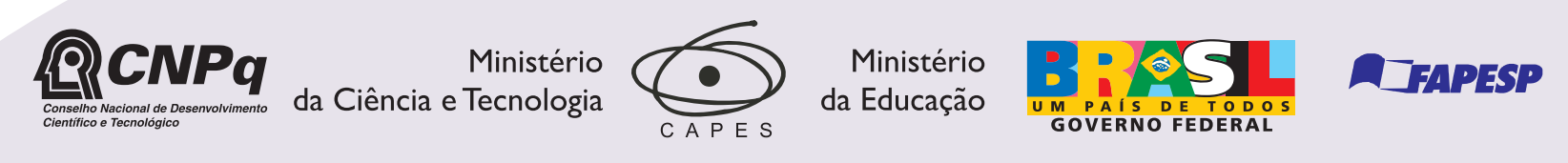

Institutional Sponsors

songo
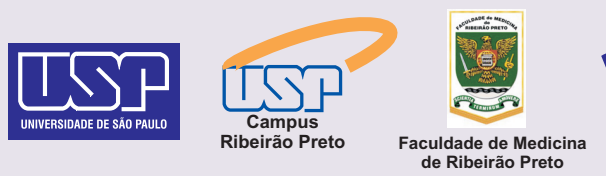

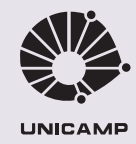

† SHIMADZu

UNICAMP

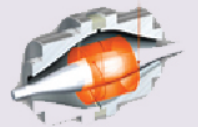

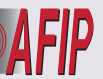

Associaçaco de Incentivo

plore High - Performance MS Orbitrap Technology analitica Thermo 


\title{
Cardiovascular effects of the intracerebroventricular injection of adrenomedullin: roles of the peripheral vasopressin and central cholinergic systems
}

\author{
B. Cam-Etoz, N. Isbil-Buyukcoskun and K. Ozluk \\ Department of Physiology, Uludag University Medical Faculty, Gorukle/Bursa, Turkey
}

\begin{abstract}
Our objective was to investigate in conscious Sprague-Dawley (6-8 weeks, 250-300 g) female rats ( $\mathrm{N}=7$ in each group) the effects of intracerebroventricularly (icv) injected adrenomedullin (ADM) on blood pressure and heart rate (HR), and to determine if $A D M$ and calcitonin gene-related peptide (CGRP) receptors, peripheral $V_{1}$ receptors or the central cholinergic system play roles in these cardiovascular effects. Blood pressure and HR were observed before and for 30 min following drug injections. The following results were obtained: 1$)$ icv ADM $(750 \mathrm{ng} / 10 \mu \mathrm{L})$ caused an increase in both blood pressure and HR $(\Delta M A P=$ $11.8 \pm 2.3 \mathrm{mmHg}$ and $\Delta \mathrm{HR}=39.7 \pm 4.8 \mathrm{bpm})$. 2) Pretreatment with a CGRP receptor antagonist (CGRP 8-37) and ADM receptor antagonist $\left(\mathrm{ADM}_{22-52}\right)$ blocked the effect of central ADM on blood pressure and HR. 3) The nicotinic receptor antagonist mecamylamine $(25 \mu \mathrm{g} / 10 \mu \mathrm{L}, i c v)$ and the muscarinic receptor antagonist atropine $(5 \mu \mathrm{g} / 10 \mu \mathrm{L}$, icv) prevented the stimulating effect of ADM on blood pressure. The effect of ADM on HR was blocked only by atropine $\left(5 \mu \mathrm{g} / 10 \mu \mathrm{L}\right.$, icv). 4) The $\mathrm{V}_{1}$ receptor antagonist [ $\beta$-mercapto- $\beta$ - $\beta$-cyclopentamethylenepropionyl $\left.{ }^{1}, \mathrm{O}-\mathrm{me}-\mathrm{Tyr}^{2}{ }^{2} \mathrm{Arg}^{8}\right]$-vasopressin $(\mathrm{V} 2255 ; 10 \mu \mathrm{g} / \mathrm{kg})$, that was applied intravenously, prevented the effect of ADM on blood pressure and HR. This is the first study reporting the role of specific ADM and CGRP receptors, especially the role of nicotinic and muscarinic central cholinergic receptors and the role of peripheral $V_{1}$ receptors in the increasing effects of icv ADM on blood pressure and HR.
\end{abstract}

Key words: Adrenomedullin; Blood pressure; Vasopressin; Atropine; Mecamylamine

\section{Introduction}

Adrenomedullin (ADM), a calcitonin/calcitonin generelated peptide (CGRP) with vasodilatory properties, has multiple functions in regulating cardiovascular homeostasis, and is of particular interest in the pathophysiology of hypertension (1-3). ADM shows structural homology to CGRP, and promotes its effects via activation of specific ADM and CGRP1 receptors $(3,4)$. Some of the central effects of this peptide are thought to be mediated by specific receptors and CGRP1 receptors, similar to the peripheral mechanism $(5,6)$. ADM was originally isolated from pheochromocytoma tissue and subsequently found to be produced in many peripheral tissues as well as in the central nervous system (CNS) (7-10). Intravenous (iv) administration of ADM causes vasodilatation and a reduction of arterial pressure (11), but intracerebroventricular (icv) administration of ADM elevates sympathetic output and increases arterial pressure (12-15). Additionally, icv ADM stimulates the hypothalamo-neurohypophyseal axis of rats and the production of hypothalamic nitric oxide (16). Many studies have demonstrated that icv ADM increased blood pressure and heart rate (HR) via central sympathetic stimulation. The action of central ADM might involve other central mechanisms such as central cholinergic stimulation. The central sympathetic stimulation and central cholinergic neurotransmission relationship has not been demonstrated in the mechanisms of central ADM. Enhancement of central cholinergic neurotransmission is very effective in increasing blood pressure. Previous studies have shown that central cholinergic stimulation or central cholinomimetic injection causes increases in blood pressure via the activation of sympathetic discharge (17-20). The action of centrally administered ADM might involve other mechanisms with peripheral $V_{1}$ receptors since there are several reports that icv administration of ADM increased c-fos mRNA and FOS protein in many areas of the hypothalamus, including the paraventricular nucleus (PVN) and supraoptic nucleus

Correspondence: B. Cam-Etoz, Department of Physiology, Uludag University Medical Faculty, 16059 Gorukle/Bursa, Turkey.

Fax: +90-224-442-8832. E-mail: mbetul@uludag.edu.tr

Received March 21, 2011. Accepted February 13, 2012. Available online March 2, 2012. Published March $19,2012$. 
(SON) $(7,8)$. Both the PVN and SON contain neurons that produce arginine vasopressin (AVP) and/or oxytocin. Taylor at al. (21) have previously demonstrated that brainderived ADM is a physiologic regulator of AVP secretion. Icv administration of ADM stimulated AVP release, while ribozyme impairment of brain-derived ADM prevented an appropriate AVP response to dehydration challenges. A previous study by our group demonstrated that peripheral $V_{1}$ receptors act as mediators of the central effects of other vasoactive peptides such as icv glucagon-like peptide-1 (22) and therefore peripheral $\mathrm{V}_{1}$ receptors may act as mediators for the central cardiovascular effects of ADM. In this study, we present data that suggest roles of ADM and CGRP receptors, peripheral vasopressin and central cholinergic system in the cardiovascular responses to ADM.

\section{Material and Methods}

We used Sprague-Dawley rats weighing 250-300 g, from the Uludag University Experimental Animal Raising, Application and Research Center. The rats were taken from the experimental animal center and kept under a 12-h light/ dark cycle, with a temperature of $18-24^{\circ} \mathrm{C}$, and $4-6$ rats to a cage with food and water provided ad libidum. Experiments began after permission was obtained from the Uludag University Animal Care and Use Committee.

For blood pressure recordings, a catheter (PE 50) filled with heparinated saline $(100 \mathrm{U} / \mathrm{mL})$ was placed into the right femoral artery of rats under ether anesthesia. Another catheter (PE 10) for iv injections was placed into the femoral vein. The arterial and venous cannulas were then passed through the skin of the back of the neck and fixed there. For icv cannulation, a hole was created $1.5 \mathrm{~mm}$ to the right of the midline and $1-1.5 \mathrm{~mm}$ behind the bregma in the skull and a cannula (prepared by cutting a $20-\mathrm{G}$ hypodermic stainless steel needle) $10 \mathrm{~mm}$ in length was placed through this hole below the skull surface, with the exposed part fixed to the skull with dental acrylic.

After the surgical procedures, the rats were placed in individual boxes and allowed to recover for 3-4 $\mathrm{h}$. No signs of pain were observed in the rats during the recovery period. After recovery, the arterial catheter was connected to the volumetric pressure transducer (BPT300). Arterial blood pressure and HR were monitored continuously using a BIOPAC Data Acquisition Unit (MP30) to which this transducer was connected. Mean arterial blood pressure (MAP, mmHg) and HR (bpm) were monitored. The rats were placed in a box where they could move freely, with the arterial catheter positioned at the same level as the volumetric pressure transducer. They were then stabilized 30 min later. Baseline arterial pressure and HR values were recorded for 10-15 min before drug administration.

The study was planned as four series of experiments. The first series investigated the effect of ADM injected icv on blood pressure and HR. Rats received icv ADM (250,
500 , and $750 \mathrm{ng} / 10 \mu \mathrm{L})$ or icv physiological saline $(10 \mu \mathrm{L}$; $\mathrm{N}=21$ ).

In the second series, the rats were injected with the ADM receptor antagonist $\mathrm{ADM}_{22-52}(1 \mu \mathrm{g} / 10 \mu \mathrm{L}$, icv $)$ or $\mathrm{CGRP}_{8-37}$ $(5 \mu \mathrm{g} / 10 \mu \mathrm{L}, i c v)$ to determine whether the effects of icv ADM on blood pressure and HR were mediated by central receptors. Physiological saline $(10 \mu \mathrm{L}$, icv $)$ or ADM $(750 \mathrm{ng} / 10 \mu \mathrm{L}$, icv) was administered 10 min after the $A D M_{22-52}$ injection and 20 min after the $\mathrm{CGRP}_{8-37}$ injection $(\mathrm{N}=28)$.

The third series investigated the role of the central cholinergic system in mediating the effects of icv ADM on blood pressure and HR. Physiological saline $(10 \mu \mathrm{L}$, icv) or ADM (750 ng/10 mL, icv) was administered 15 min after injection of the muscarinic receptor antagonist atropine $(5 \mu \mathrm{g} / 10 \mu \mathrm{L}$, icv) or the nicotinic receptor antagonist mecamylamine (25 $\mu \mathrm{g} / 10 \mu \mathrm{L}, i c v ; \mathrm{N}=28$ ).

In the fourth series of experiments, the vasopressin $\mathrm{V}_{1}$ antagonist $\left[\beta\right.$-mercapto- $\beta-\beta$-cyclopentamethylenepropionyl ${ }^{1}$, O-me-Tyr ${ }^{2}$, Arg $^{8}$ ]-vasopressin (V2255; $10 \mu \mathrm{g} / \mathrm{kg}$, iv), was injected 5 min before the injection of ADM $(750 \mathrm{ng} / 10 \mu \mathrm{L}$, icv) or physiological saline $(10 \mu \mathrm{L}$, icv) to investigate the role of the peripheral $\mathrm{V}_{1}$ receptor on the cardiovascular effects of ADM ( $N=14)$.

At the end of the experiments, $5 \mu \mathrm{L}$ methylene blue solution was injected into the cerebral ventricle through the cannula and the location of the inner end of the cannula was confirmed for each rat. The brains were removed following decapitation and the location of the icv cannula was checked again.

Adrenomedullin, $\mathrm{CGRP}_{8-37}, \mathrm{ADM}_{22-52}$, atropine sulfate, mecamylamine chloride, and V2255 were purchased from Sigma (USA). All drugs were prepared in saline $(0.9 \% \mathrm{NaCl})$. The doses of the drugs provided in the text were prepared in $10 \mu \mathrm{L}$ for icv injections, and the injections were performed with a Hamilton microinjector. The doses of iv administered drugs were calculated to final volumes of $1 \mathrm{~mL} / \mathrm{kg}$.

Blood pressure and HR values were recorded over a period of $30 \mathrm{~min}$. The data recorded for each animal before the injections are the baseline values. $\triangle M A P$ and $\triangle H R$ differences were calculated by substracting the baseline values from the recorded values at each $5 \mathrm{~min}$. The groups were then compared to the control group. Data are reported as means \pm SEM and analysis of variance (ANOVA) was used to determine statistical significance. Differences were considered to be significant at $\mathrm{P}<0.05$.

\section{Results}

\section{Cardiovascular effects of icv adrenomedullin}

Prior to drug injection, the resting blood pressure and $\mathrm{HR}$ of the conscious, freely moving rats were $120 \pm 2 \mathrm{mmHg}$ and $303 \pm 6$ bpm, respectively. These values were compared to the values obtained every fifth minute for a total period of $30 \mathrm{~min}$. Injection of icv ADM $(250,500 \mathrm{ng} / 10 \mu \mathrm{L})$ produced increases in both blood pressure and HR but these changes 
did not differ statistically from basal values.

Administration of $750 \mathrm{ng} / 10 \mu \mathrm{L}$ icv ADM produced statistically significant increases in both MAP and HR. MAP was highest $(\triangle \mathrm{MAP}=11.8 \pm 2.3 \mathrm{mmHg})$ at $5-15 \mathrm{~min}$, then decreased gradually, but was still significantly higher at 30 min compared to saline-treated rats (Figure 1A). ADM (750 $\mathrm{ng} / 10 \mu \mathrm{L}, i c v)$ also induced an increase in $\mathrm{HR}$, which was maximal $(\Delta \mathrm{HR}=39.7 \pm 4.8 \mathrm{bpm})$ at $30 \mathrm{~min}$ (Figure $1 \mathrm{~B})$. These increases were statistically significant compared to the saline-treated rats. Therefore, we used this dose in the other series of our study.

\section{Effects of pretreatment with adrenomedullin antagonists on the pressor effects of icv adrenomedullin}

$\mathrm{ADM}_{22-52}$ and $\mathrm{CGRP}_{8-37}$ are receptor antagonists of CGRP and ADM. Pretreatment with both ADM22-52 (1 $\mu \mathrm{g} / 10 \mu \mathrm{L}, i c v)$ and $\mathrm{CGRP}_{8-37}(5 \mu \mathrm{g} / 10 \mu \mathrm{L}$, icv) significantly attenuated ADM (750 ng/10 $\mu \mathrm{L}, i c v)$-induced changes in
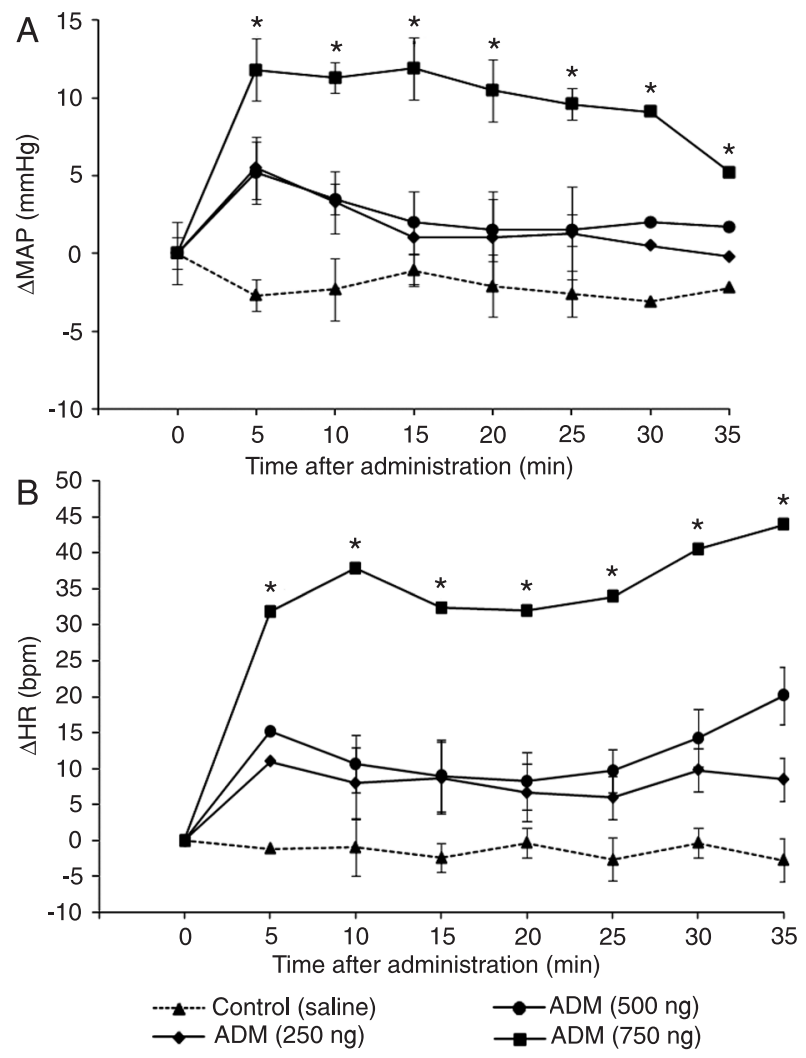

Figure 1. Time course of changes in mean arterial pressure $(A ; \triangle M A P)$ and heart rate $(B ; \Delta \mathrm{HR})$ after icv injection of adrenomedullin (ADM); 250, 500, and $750 \mathrm{ng} / 10 \mu \mathrm{L}$ ) and saline (10 $\mu \mathrm{L})$. $\triangle \mathrm{MAP}$ and $\triangle \mathrm{HR}$ values were calculated by substracting the baseline values from the recorded values at each $5 \mathrm{~min}$. Data are reported as means \pm SEM for 7 rats in each group. ${ }^{*} P<0.05$ compared to the respective values for saline treatment (Tukey-Kramer multiple comparisons test). $\triangle \mathrm{MAP}$ and $\triangle \mathrm{HR}$ (Figure 2).

\section{Effects of pretreatment with central cholinergic system antagonists on the pressor effects of icv adrenomedullin}

Rats were injected with either the nicotinic receptor antagonist, mecamylamine $(25 \mu \mathrm{g} / 10 \mu \mathrm{L} ;$ icv), or the muscarinic receptor, atropine ( $5 \mu \mathrm{g} / 10 \mu \mathrm{L} ; i c v)$, followed 15 min later by $750 \mathrm{ng} / 10 \mu \mathrm{L}$ icv ADM or saline. Both mecamylamine and atropine prevented the rise in blood pressure induced by ADM (Figure 3A). The ADM-induced increase in HR was
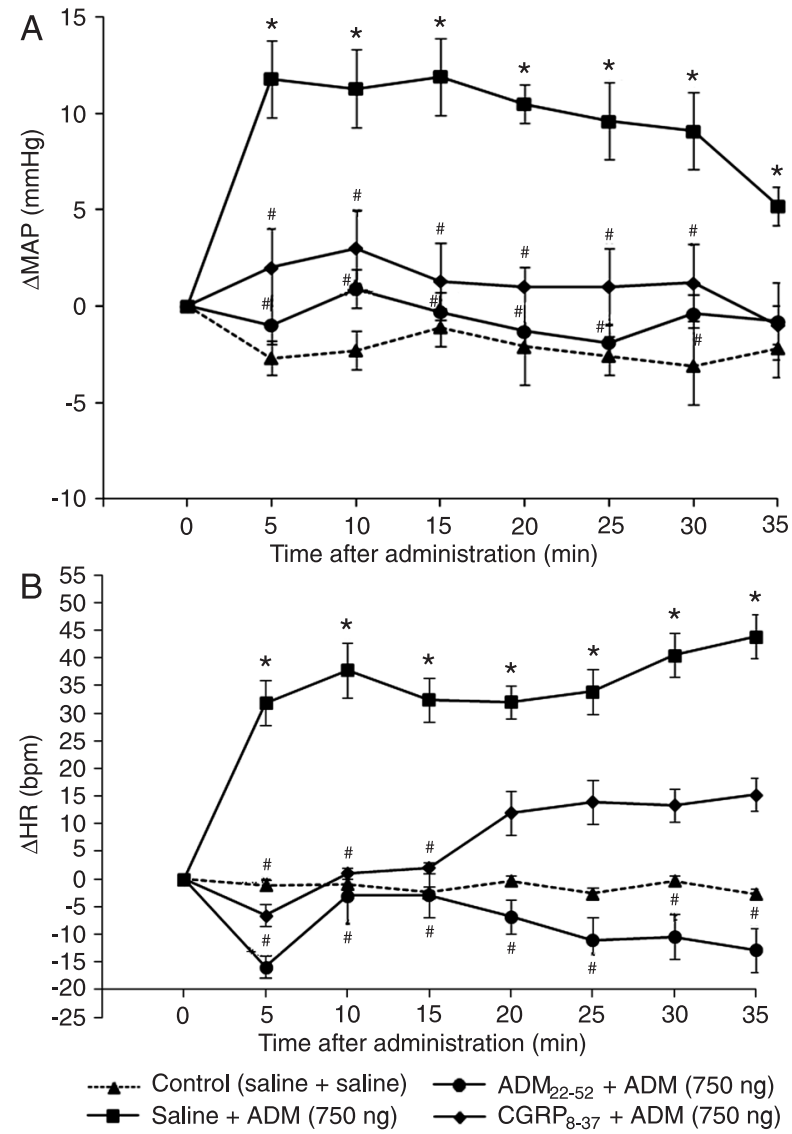

Figure 2. Effect of the adrenomedullin (ADM) receptor antagonist $A_{2 D} M_{22-52}$ and calcitonin gene-related peptide (CGRP $\left.{ }_{8-37}\right)$ on blood pressure $(A)$ and heart rate $(B)$ responses to icv ADM. Rats received $\mathrm{ADM}_{22-52}(1 \mu \mathrm{g} / 10 \mu \mathrm{L}$, icv $) 10 \mathrm{~min}$, or $\mathrm{CGRP}_{8-37}(5 \mu \mathrm{g} / 10$ $\mu \mathrm{L}$, icv) $20 \mathrm{~min}$ before icv ADM $(750 \mathrm{ng} / 10 \mu \mathrm{L})$ injection. Blood pressure and heart rate were recorded for 30 min following ADM injection. Mean arterial pressure $(\triangle M A P)$ and heart rate $(\triangle H R)$ values were calculated by substracting the baseline values from the recorded values at each $5 \mathrm{~min}$. Data are reported as means \pm SEM for 7 rats in each group. ${ }^{*} \mathrm{P}<0.05$ compared with respective values for saline treatment (Tukey-Kramer multiple comparisons test); ${ }^{\mathrm{P}}<0.05$ compared with respective values for icv ADMtreated group (Tukey-Kramer multiple comparisons test). 

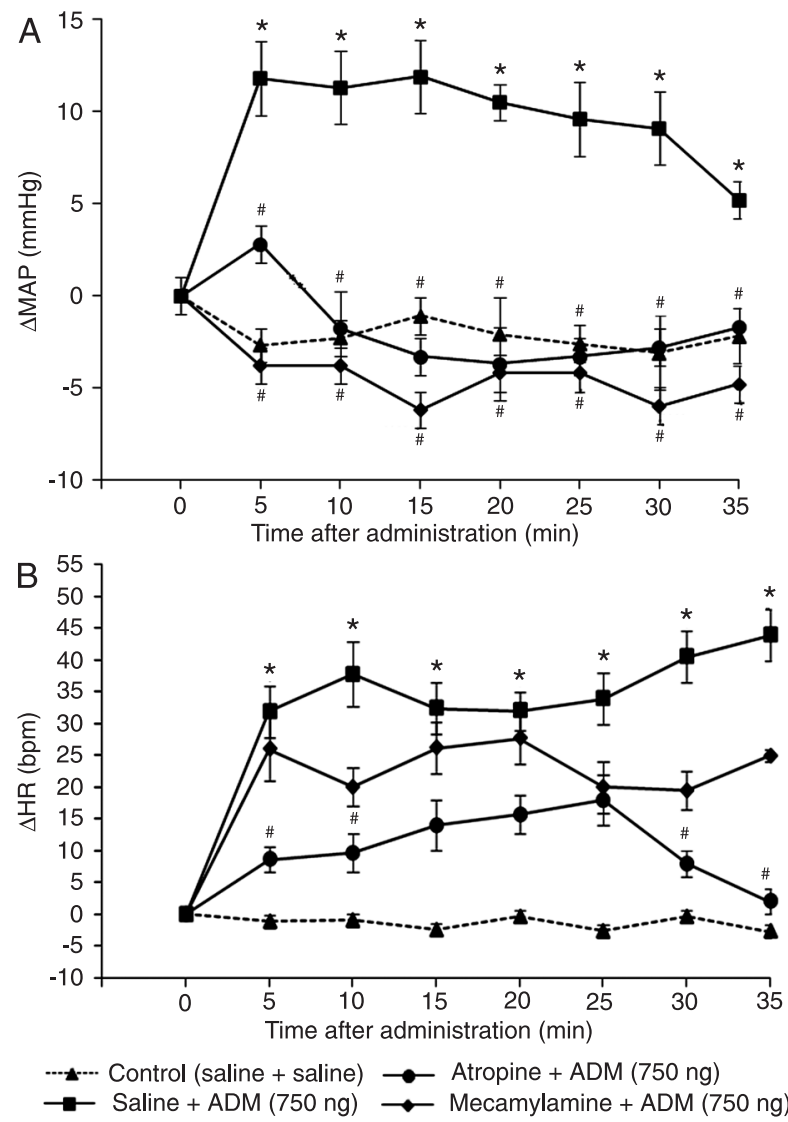

Figure 3. Effect of cholinergic muscarinic receptor blockade and cholinergic nicotinic receptor blockade on blood pressure $(A)$ and heart rate $(B)$ responses to icv adrenomedullin (ADM). Rats received atropine sulfate $(5 \mu \mathrm{g} / 10 \mu \mathrm{L}$, icv) $15 \mathrm{~min}$ or mecamylamine $(25 \mu \mathrm{g} / 10 \mu \mathrm{L}, i c v) 15$ min before icv ADM $(750 \mathrm{ng} / 10 \mu \mathrm{L})$ injection. Blood pressure and heart rate $(H R)$ were recorded for 30 min following ADM injection. Mean arterial pressure ( $\triangle M A P)$ and $\triangle H R$ values were calculated by substracting the baseline values from the recorded values at each $5 \mathrm{~min}$. Data are reported as means \pm SEM for 7 rats in each group. ${ }^{*} P<0.05$ compared with respective values for saline treatment (Tukey-Kramer multiple comparisons test); ${ }^{\mathrm{P}}<0.05$ compared with respective values for icv ADM-treated group (Tukey-Kramer multiple comparisons test).

blocked by atropine but not by mecamylamine (Figure 3B). The icv administration of each drug alone did not induce any significant changes in cardiovascular parameters (data not shown).

\section{Effects of pretreatment with vasopressin $\mathrm{V}_{\mathbf{1}}$ receptor antagonists on the pressor effects of icv adrenomedullin}

Rats were injected with the specific vasopressin $V_{1}$ receptor antagonist, V2255 (10 $\mu \mathrm{g} / \mathrm{kg}$, iv) through the cannula 5 min before icv ADM or icv saline injection. The vasopressin $V_{1}$ receptor antagonist significantly prevented
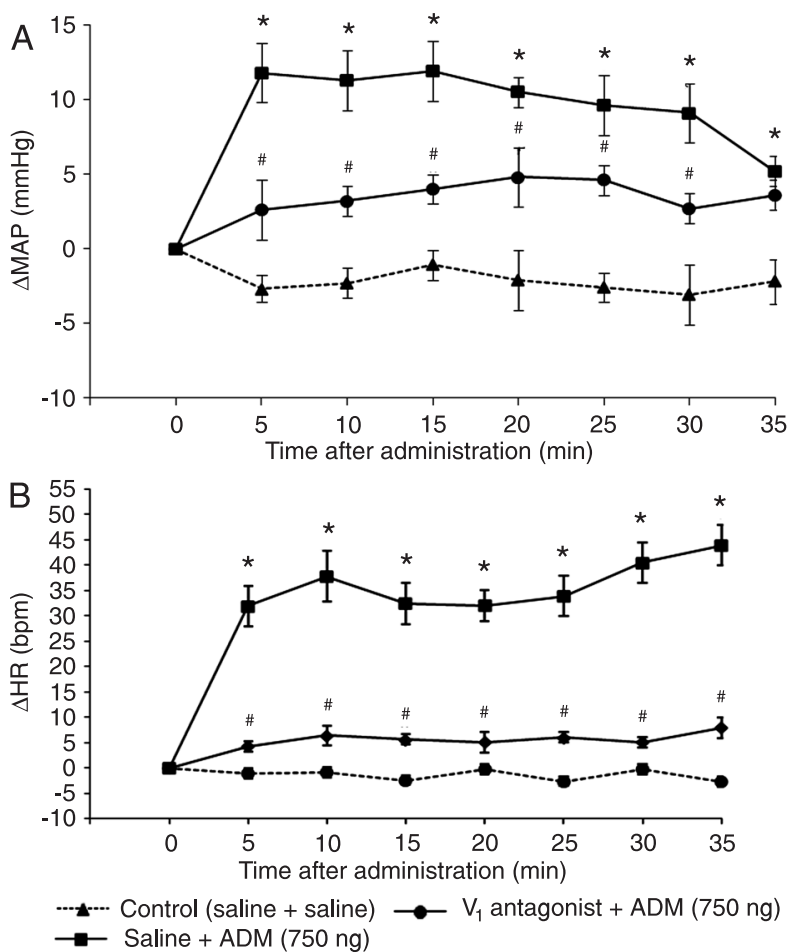

Figure 4. Role of the vasopressin $V_{1}$ receptor antagonist in the blood pressure $(A)$ and heart rate $(B)$ responses to icV adrenomedullin (ADM). Rats received the $\mathrm{V}_{1}$ receptor antagonist (10 $\mu \mathrm{g} / 10 \mu \mathrm{L}$, icv) $5 \mathrm{~min}$ before icv ADM $(750 \mathrm{ng} / 10 \mu \mathrm{L})$ injection. Blood pressure and heart rate (HR) were recorded for $30 \mathrm{~min}$ following ADM injection. Mean arterial pressure $(\triangle M A P)$ and $\triangle H R$ values were calculated by substracting the baseline values from the recorded values at each $5 \mathrm{~min}$. Data are reported as means \pm SEM for 7 rats in each group. ${ }^{*} P<0.05$ compared with respective values for saline treatment (Tukey-Kramer multiple comparisons test); ${ }^{\# P}<0.05$ compared with respective values for icv ADMtreated group (Tukey-Kramer multiple comparisons test).

the ADM-induced increase in blood pressure and HR (Figure $4 A, B)$. In normal rats, pretreatment with vasopressin $V_{1}$ receptor antagonist itself did not change blood pressure (data not shown).

\section{Discussion}

Recent studies have shown that ADM is involved in the regulation of MAP although ADM has different cardiovascular effects when administered peripherally or centrally. Intravenous administration of ADM causes a long-lasting and dose-dependent decrease in arterial blood pressure $(1,3,11)$. On the other hand, icv administration of ADM increases MAP, HR and sympathetic activity (12-16). However, central administration of ADM exerted multiple central effects in different areas. Microinjection of ADM into the hypothalamic PVN induced a significant decrease of blood pressure (23), whereas microinjection of ADM into the rostral 
ventrolateral medulla caused a significant increase of blood pressure accompanied by an increase of renal sympathetic output $(24,25)$. We observed that icv ADM administered at a dose of $750 \mathrm{ng} / 10 \mu \mathrm{L}$ increased blood pressure and HR in rats and these increased values did not return to basal values after $30 \mathrm{~min}$. ADM has structural homology with CGRP, and specific ADM and CGRP1 receptors interfere with the effects of these peptides (2-4). The CGRP1 receptor antagonist $\mathrm{CGRP}_{8-37}$ has been observed to block some ADM effects. The central effects of this peptide are thought to be mediated by specific receptors and CGRP1 receptors, similar to the peripheral mechanism $(5,6)$. In the present study, the effect of icv ADM on blood pressure and $\mathrm{HR}$ was blocked in rats pretreated with $\mathrm{ADM}_{22-52}$ and CGRP $_{8-37}$, suggesting that ADM acts through specific ADM receptors and CGRP1 receptors in agreement with other studies $(5,6)$. Takahashi et al. (13) observed that central administration of the CGRP antagonist CGRP $8-37$ blocked the effects of ADM. Saita et al. (14) showed that both $\mathrm{CGRP}_{8-37}$ and the ADM-specific receptor antagonist $A_{22-52}$ block the cardiovascular effects of ADM. On the other hand, Samson et al. (15) found that $\mathrm{CGRP}_{8-37}$ did not prevent the hypertensive effects of central ADM. It is not known which receptor binds more strongly or is more specific in regulating the effects of ADM. We found that the specific receptor antagonist, $A D M_{22-52}$, blocked both ADM-induced increases in blood pressure and HR more efficiently than CGRP $_{8-37}$. This result is consistent with those reported by Saita et al. (14).

Involvement of cholinergic neurons in the regulation of blood pressure has been demonstrated (17-20). Central cholinergic stimulation or central cholinomimetic injection causes increases in blood pressure via the activation of sympathetic discharge. Sympathoadrenergic activation has been shown to be caused by icv ADM (13-16), indicating the importance of the role of cholinergic receptors in mediating the effects of central ADM. Previous studies have suggested that central muscarinic receptor stimulation plays an important role in cardiovascular regulation $(18,26)$. I c v administration of muscarinic agonists into the posterior hypothalamic nucleus or medulla of rats evoked pressor and cardioacceleratory responses $(27,28)$. Circulating catecholamines and sympathetic neural outflow are elevated in animals after central muscarinic stimulation $(29,30)$.

In the present study, we have shown the relationship between the central cholinergic system and icv ADM. Our results suggest that the pressor effect of ADM might be mediated by the central cholinergic receptors in normotensive rats. This is the first study reporting that the ADM-induced blood pressure increase was prevented by a cholinergic receptor antagonist. Both the nicotinic receptor antagonist mecamylamine and the muscarinic receptor antagonist atropine prevented ADM-induced blood pressure increase. This result suggests that nicotinic and muscarinic receptors play roles in the effects of ADM on blood pressure. Muscarinic receptors have been shown to be present in areas involved in regulating cardiovascular responses to cholinergic agonists and these receptors are widely expressed in the CNS, especially in autonomic centers, and they control a variety of neuronal functions $(29,30)$. ADM-producing neurons are prominent in autonomic centers of the CNS and these centers contain muscarinic receptors (7-10,30). Icv ADM increases nicotinic and muscarinic neurotransmission by presynaptic mechanisms and also activates nicotinic and muscarinic receptors as a direct agonist. Buys et al. (31) have shown that ADM up-regulates the expression of the M2 muscarinic receptor in both P19 isolated atrial cells and in adult rats (31). Interestingly, the nicotinic receptor antagonist mecamylamine did not alter the increase in HR whereas the muscarinic receptor antagonist atropine blocked it. Nicotinic receptor blockage decreased blood pressure through presynaptic cholinergic activation but did not alter HR due to the possibility of a reflex tachycardiac response. The effect of ADM on HR was prevented by the central muscarinic receptor antagonist. Furthermore, central M1 receptor activation appears to have an important role in mediating the baroreflex (29) and the Bezold-Jarisch reflex (32) in rats. Thus, alterations in muscarinic receptor activity in the brain may influence the control of cardiovascular function by the autonomic nervous system.

The distribution of ADM-positive neurons in both the parvo- and magnocellular division of the PVN suggests that ADM participates in the regulation of the hypothalamus-pituitary-adrenal, neurohypophyseal functions and of autonomic responses (9-12). The PVN and SON of the hypothalamus are known to secrete vasopressin and oxytocin and to have important functions in autonomic and neuroendocrine regulation. Icvadministered ADM localizes in the PVN and SON $(9,10)$. A study has shown that ADM inhibits the arginine-vasopressin production induced by hypovolemia and osmotic stimulation and to stimulate oxytocin production in the rat hypothalamus (33), but Taylor et al. (21) have shown that central administration of ADM leads to a dose-related increase in plasma vasopressin levels. We observed that administration of a vasopressin $V_{1}$ receptor antagonist blocked the blood pressure and HR stimulating effects of $A D M$, suggesting that $V_{1}$ receptors play a role in the cardiovascular effects of central ADM.

In conclusion, icv ADM can effectively increase blood pressure and $\mathrm{HR}$ and these effects might occur by way of the specific ADM and CGRP receptors, peripheral $V_{1}$ receptors and central nicotinic and muscarinic cholinergic receptors.

\section{Acknowledgments}

Research supported by a grant (\#SBAG-105S508) from the Scientific and Technical Research Council of Turkey (TUBITAK). 


\section{References}

1. Kitamura K, Kangawa K, Kawamoto M, Ichiki Y, Nakamura $\mathrm{S}$, Matsuo $\mathrm{H}$, et al. Adrenomedullin: a novel hypotensive peptide isolated from human pheochromocytoma. Biochem Biophys Res Commun 1993; 192: 553-560.

2. Wimalawansa SJ. Amylin, calcitonin gene-related peptide, calcitonin, and adrenomedullin: a peptide superfamily. Crit Rev Neurobiol 1997; 11: 167-239.

3. Joy PH, Supriya K, David MS. Adrenomedullin, a multifunctional regulatory peptide. Endocr Rev 2000; 21: 138-167.

4. Hay DL, Conner AC, Howitt SG, Smith DM, Poyner DR. The pharmacology of adrenomedullin receptors and their relationship to CGRP receptors. J Mol Neurosci 2004; 22: 105-113.

5. Hay DL, Smith DM. Adrenomedullin receptors: molecular identity and function. Peptides 2001; 22: 1753-1763.

6. Eguchi S, Hirata Y, Kano H, Sato K, Watanabe Y, Watanabe TX, et al. Specific receptors for adrenomedullin in cultured rat vascular smooth muscle cells. FEBS Lett 1994; 340: 226-230.

7. Serrano J, Uttenthal LO, Martinez A, Fernandez AP, de Velasco JM, Alonso D, et al. Distribution of adrenomedullin-like immunoreactivity in the rat central nervous system by light and electron microscopy. Brain Res 2000; 853: 245-268.

8. Ueta Y, Hara Y, Kitamura K, Kangawa K, Eto T, Hattori Y, et al. Action sites of adrenomedullin in the rat brain: functional mapping by Fos expression. Peptides 2001; 22: 1817-1824.

9. Ueta Y, Kitamura K, Isse T, Shibuya I, Kabashima N, Yamamoto $\mathrm{S}$, et al. Adrenomedullin-immunoreactive neurons in the paraventricular and supraoptic nuclei of the rat. Neurosci Lett 1995; 202: 37-40.

10. Satoh F, Takahashi K, Murakami O, Totsune K, Sone M, Ohneda $\mathrm{M}$, et al. Immunocytochemical localization of adrenomedullinlike immunoreactivity in the human hypothalamus and the adrenal gland. Neurosci Lett 1996; 203: 207-210.

11. Fukuhara M, Tsuchihashi T, Abe I, Fujishima M. Cardiovascular and neurohormonal effects of intravenous adrenomedullin in conscious rabbits. Am J Physiol 1995; 269: R1289-R1293.

12. Shan J, Stachniak T, Jhamandas JH, Krukoff TL. Autonomic and neuroendocrine actions of adrenomedullin in the brain: mechanisms for homeostasis. Regul Pept 2003; 112: 33-40.

13. Takahashi H, Watanabe TX, Nishimura M, Nakanishi T, Sakamoto M, Yoshimura M, et al. Centrally induced vasopressor and sympathetic responses to a novel endogenous peptide, adrenomedullin, in anesthetized rats. Am J Hypertens 1994; 7: 478-482.

14. Saita M, Shimokawa A, Kunitake T, Kato K, Hanamori T, Kitamura $\mathrm{K}$, et al. Central actions of adrenomedullin on cardiovascular parameters and sympathetic outflow in conscious rats. Am J Physiol 1998; 274: R979-R984.

15. Samson WK, Murphy TC, Resch ZT. Central mechanisms for the hypertensive effects of preproadrenomedullin-derived peptides in conscious rats. Am J Physiol 1998; 274: R1505R1509.

16. Shan J, Krukoff TL. Intracerebroventricular adrenomedullin stimulates the hypothalamic-pituitary-adrenal axis, the sympathetic nervous system and production of hypothalamic nitric oxide. J Neuroendocrinol 2001; 13: 975-984.

17. Arslan BY, Ulus IH, Savci V, Kiran BK. Effects of intracerebroventricular injected choline on cardiovascular functions and sympathoadrenal activity. J Cardiovasc Pharmacol
1991; 17: 814-821.

18. Brezenoff HE, Giuliano R. Cardiovascular control by cholinergic mechanisms in the central nervous system. Annu Rev Pharmacol Toxicol 1982; 22: 341-381.

19. Willette RN, Punnen S, Krieger AJ, Sapru HN. Cardiovascular control by cholinergic mechanisms in the rostral ventrolateral medulla. J Pharmacol Exp Ther 1984; 231: 457-463.

20. Buccafusco JJ. The role of central cholinergic neurons in the regulation of blood pressure and in experimental hypertension. Pharmacol Rev 1996; 48: 179-211.

21. Taylor MM, Baker JR, Samson WK. Brain-derived adrenomedullin controls blood volume through the regulation of arginine vasopressin production and release. Am J Physiol Regul Integr Comp Physiol 2005; 288: R1203-R1210.

22. Isbil-Buyukcoskun N, Gulec G. Effects of intracerebroventricularly injected glucagon-like peptide-1 on cardiovascular parameters; role of central cholinergic system and vasopressin. Regul Pept 2004; 118: 33-38.

23. Smith PM, Ferguson AV. Adrenomedullin acts in the rat paraventricular nucleus to decrease blood pressure. J Neuroendocrinol 2001; 13: 467-471.

24. Ji SM, He RR. Microinjection of adrenomedullin into rostral ventrolateral medulla increases blood pressure, heart rate and renal sympathetic nerve activity in rats. Sheng $\mathrm{Li} X u \mathrm{e}$ Bao 2002; 54: 460-466.

25. $\mathrm{Xu} Y, \mathrm{Krukoff} T \mathrm{TL}$. Adrenomedullin in the rostral ventrolateral medulla increases arterial pressure and heart rate: roles of glutamate and nitric oxide. Am J Physiol Regul Integr Comp Physiol 2004; 287: R729-R734.

26. Brezenoff HE, Xiao YF. Acetylcholine in the posterior hypothalamic nucleus is involved in the elevated blood pressure in the spontaneously hypertensive rat. Life Sci 1989; 45: $1163-1170$.

27. Martin JR. Pressor response to posterior hypothalamic administration of carbachol is mediated by muscarinic M3 receptor. Eur J Pharmacol 1992; 215: 83-91.

28. Scheucher A, Pirola CJ, Balda MS, Dabsys SM, Alvarez AL, Finkielman S, et al. Muscarinic M1 receptors in the lateral septal area mediate cardiovascular responses to cholinergic agonists and bradykinin: supersensitivity induced by chronic treatment with atropine. Neuropharmacology 1987; 26: 181-185.

29. Taira CA, Enero MA. Central muscarinic involvement in cardiovascular control in sinoaortic-denervated rats. Eur J Pharmacol 1989; 159: 265-272.

30. Levey Al, Edmunds SM, Koliatsos V, Wiley RG, Heilman CJ. Expression of m1-m4 muscarinic acetylcholine receptor proteins in rat hippocampus and regulation by cholinergic innervation. J Neurosci 1995; 15: 4077-4092.

31. Buys S, Smih F, Pathak A, Philip-Couderc P, Verwaerde $\mathrm{P}$, Montastruc JL, et al. Adrenomedullin upregulates M2muscarinic receptors in cardiomyocytes from P19 cell line. Br J Pharmacol 2003; 139: 1219-1227.

32. Saito K, Yoshioka M, Kohya T, Kitabatake A. Involvement of muscarinic M1 receptor in the central pathway of the serotonin-induced Bezold-Jarisch reflex in rats. J Auton Nerv Syst 1994; 49: 61-68.

33. Yokoi H, Arima H, Murase T, Kondo K, Iwasaki Y, Oiso Y. Intracerebroventricular injection of adrenomedullin inhibits vasopressin release in conscious rats. Neurosci Lett 1996; 216: 65-67. 